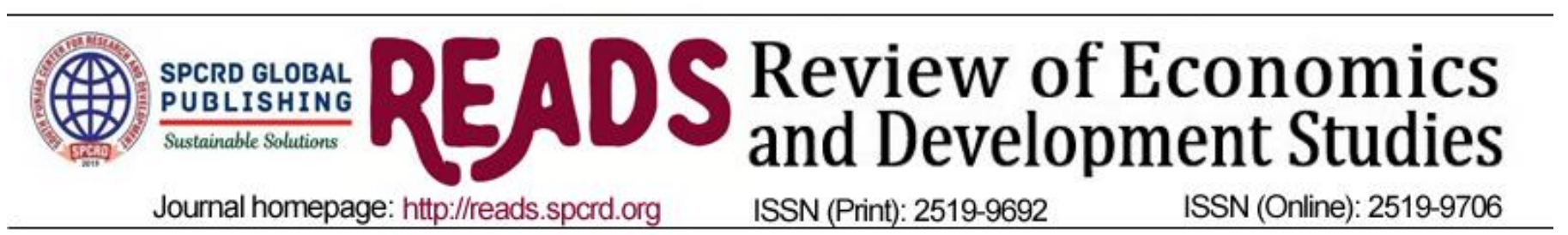

\title{
Women Empowerment and Micro Finance Programs: A Case Study of District Khairpur
}

\author{
${ }^{a}$ Misbah Rahman, ${ }^{b}$ Muhammad Saleem Rahpoto, ${ }^{c}$ Ghulam Muhammad Mangnejo \\ ${ }^{a}$ Ph.D Sholar, Department of Economics, Shah Abdul Latif University Khairpur, Pakistan \\ ${ }^{\mathrm{b}}$ Professor, Department of Economics, Shah Abdul Latif University Khairpur, Pakistan \\ ${ }^{c}$ Assistant Professor of Economics, Shaikh Ayaz University, Shikarpur, Pakistan \\ Email: mangnejogm81@gmail.com
}

\begin{tabular}{l}
\hline ARTICLE DETAILS \\
\hline History: \\
Accepted 26 March 2020 \\
Available Online 31 March 2020 \\
\hline Keywords: \\
Double economy, random part, \\
lowest wages, compensation \\
\hline JEL Classification: \\
E20, E26, J30, J31 \\
\hline
\end{tabular}

DOI: $10.47067 /$ reads.v6i1.188

\begin{abstract}
The model of double monetary improvement contains the lowest wages (between difference foundations) responsible for the continuous dualism. We use 2 years of micro data from a large number of workers in Pakistan to test whether legally lowest wages have different effects on formal compensation, as opposed to the occasionally different segment. We find that the evidence from Pakistan rejects the assumptions of these models: raising the minimum wage not only extends the compensation in the city format part (big urban effort), which are enclosed through the least wages rule, nonetheless also increases the salaries of altogether other specialists, $z$ Lowest legal allowance, which is generally considered to be an occasional split and is not regularly enforced (eg, small municipal companies, large provincial companies and small country companies). Our finding also suggest that the lowest statutory minimum wages increase wages for specialists in these "random" departments more than in the urban form, and therefore may lose the normal pay gap amid these segments and city additional part, which is considered nonbinding nonetheless not governed $b$ the Least Wage Act: the freelance (in together city and provincial regions). Least salaried may therefore lead to a symmetry amid official \& casual workers, who referred to as selfemployed and paid labors. In any case, we discovery no indication that self-earned income falls by the lowest pay.
\end{abstract}

(C) 2020 The authors. Published by SPCRD Global Publishing. This is an open access article under the Creative Commons Attribution-

NonCommercial 4.0

Corresponding author's email address: mangnejogm81@gmail.com

\section{Introduction}

Microfinance has been unequivocally underlined lately for women, as they are the dynamic piece of our general workforce. To accomplish economic development, the support of women is significant. Tragically, Asian women and particularly Pakistani women are under limitations because of some conventional and social taboos and the most unfortunate of the least fortunate individuals on the 
planet. Thus, legislative and non-administrative establishments are presently concentrating on microfinance on enabling women.

In Pakistan, destitution has expanded quickly and different neediness decrease projects are required. Pakistan is an agrarian nation. Most by far of individuals rely upon agribusiness and have low wages, low expectation for everyday comforts. They have no help, no help, particularly budgetary. The circumstance of rustic territories has weakened. Ladies have a low status, live under requirements and confinements. Therefore, it is important to monetarily bolster women and they can begin a private venture. Microfinance projects bolster them monetarily. There are numerous foundations and NGOs working around there in the Kanpur area, Sind. The primary reason for these organizations is to give advances to poor women to begin their very own miniaturized scale business. Microfinance is additionally a device foe enabling women. So that, we are keen on finding the extent of microfinance in Khairpur. Objectives of the study are as under:

i. Investigate crafted by the microfinance segment in Pakistan.

ii. Investigate the significance and job of microfinance in lessening destitution and engaging women.

iii. Investigate the issues of women who are in microfinance

iv. Break down the connection among microfinance and strengthening of women

In Pakistan, it is for the most part a microfinance program, advance since the 1990s, to fortify the job of women in the public eye. Thusly, just a couple of studies have been made on the connection among microfinance and strengthening of women. The business analyst and social reformers have various perspectives in this regard microfinance is another field in the budgetary part [1], and when women acknowledge the difficulties of culture and forbidden, they can expand their status in the public eye.

Before microfinance was not efficient and there was no logical information. Microfinance started accurately by the outstanding social extremist Muhammad Yunus. The established the Grammyn Bank in Bangladesh to improve women from Bangladesh and diminish neediness. Pakistan has an agro-based nation, and women are half of our complete populace. In the event that they are latent, the improvement procedure will be extremely moderate. Most investigations demonstrate that women are progressively capable and dynamic to reimburse their advances than men, and they work genuinely and proficiently and are increasingly steady of the person. As indicated by the specialist there is a genuine case of Grameen Bank, which gives almost $96 \%$ of its microfinance administrations to women and has a United Nation rating that around $76 \%$ of microfinance administrations are being utilized by women around the globe. Muhammad Yunus stated: "Human rights acknowledged are sustenance, safe house, wellbeing and instruction, and the essential obligation of society is to ensure there is such a domain, that individuals can have such things, business is additionally right, yet society cannot give an occupation dependent on wages for all, so the option is independent work. At present, huge money, related establishments overlook right around $66 \%$ of the total populace. That is, it that I express that the privilege to credit must be given the most elevate need in the rundown of human rights. "The primary reason for the examination is too thin about the connection among microfinance and strengthening of ladies concerning Pakistan.

\section{Abstract Audit}

Microfinance, giving money related administration to poor and low-pay families. It is depicted as banking for poor people. Microfinance projects give microcredit/smaller scale credits, miniaturized scale reserve funds, small scaled protection and gathering preparing and other monetary 
administrations for low-salary and needy individuals to oversee independent ventures. Naheed (2013) says, "Engaging ladies is the way to building the eventual fate of the country."

She focused on the significance of enabling women in the public eye. This is relative and expository examination on the general condition of women in various nations, for example, Pakistan and India, the investigation additionally centers on the snags and entanglements looked by women to substantiate themselves in various segments. The examined women's duties and said she was in charge of gathering the essential needs of society. Strengthening offers fearlessness to women to battle social bad form. She additionally said that in the past women did not have equivalent rights with men. They did not claim property, not responsibility for guardians. They did not reserve the privilege to cast a ballot and did not have the ability to pick their activity. Since we have left these bleak long stretches of submission to women, yet there is requirement of a solid development to battle victimization women and sex. Strengthening is a procedure of assuming responsibility for their lives and sexual orientation correspondence. She examined the circumstance of women in Pakistan that the constitution of the Islamic Republic of Pakistan conceded equivalent rights to women and men. As indicated by the Human Development Repot 2007/2008, Pakistan's position among 93 countries enlisted in the United Nations is (GEM), which is 82. Diamond measures women's strengthening at national dimension.

As per the Global Gendering of Gender (GGG) report, ten of the world's greatest guilty parties are Yemen, Chad, Pakistan, Nepal, Saudi Arabia, Morocco, Turkey, Egypt and Oman. At the opposite end of the range, the best nations on earth to live with are Sweden, Norway, Finland, Ireland, New Zealand, the Philippines, Germany, Denmark, Ireland and Spain. GGG gathered information from 128 nations to build up an extensive logical list [1]. Dr. Muhammad Saleem and Missbah (2013) cleared the situation of women in the Pakistani constitutional they said in their article that as indicated by the 1947 Order in Pakistan, the vote on women's rights rose. In 1956 [7], she got the privilege to cast a ballot. In Pakistan, numerous means have taken on the 1973 constitution to improve the status of women. They have conceded the privilege to state administrations and remote administrations. $10 \%$ share fixed at the national get together and 5\% in the common gathering assigned for women. In 1985, the portion of the national Assembly expanded from 10\% to 20\%. Article 25 expressed that all natives are equivalent under the steady gaze of the law and reserve the privilege to approach security of the law, there must be no segregation on grounds of sex just [2], nothing in this article does not keep the state from making any arrangement for the assurance of women and youngsters.

Article 32 empowers nearby government establishments. Article 34 states that women are completely associated with all circles of national life. Article 35 states that the state must ensure marriage, family, mother and youngsters. On January 29, 2010. The president of Pakistan marked the “Ladies' Labor Protection Act 2009" [5], which Parliament passed on January 20, 2010. The president marked two extra bills in December 2012, condemning the crude practices of Baths, Watasats, and the marriage of the Holy Qur'an, who utilized women as tradable products for debates. The administration has additionally set up a unique working gathering inside the Sindh locale to act against the act of packs to build up assistance lines and workplaces in the Sukkur, Jacobabad, Larkana and Khairpur regions [2]. On January 31, 1976, the Pakistan women's Rights Commission setup under the aegis of the Ministry of Justice and parliamentary issues, including unmistakable women's legislators, social specialists and expert women from various circles of life [7]. The Commission has tended to the issue of women's legitimate changes and monetary conditions, the women's legitimate changes and monetary conditions. The women's Unit made in 1979 and in this manner turned into a service in 1989. Because of women's interest and weight, and because of general familiarity with the ominous conditions encompassing the all-out number of women, the planning Committee set up an Expert Working Group on Development 
Programs of women. The first of its sort - to give explicit suggestions for the 6th five years of age plan (1983-88) to assess and propose measures to upgrade ladies' cooperation in various national exercises. (Shafqat, Sultana, 1995).

Naheed (2013) out in his article that "at the Copenhagen Summit in 1993 and at the International Conference on Population and Development in Cairo 1884, governments subscribed to the strengthening of ladies. This dedication is streamlined and figured in an unmistakable strategy at the Fourth World Conference on women in Beijing in 1995, when governments focused on "engaging and propelling ladies, shame, for example [6], youngster relational unions, including the privilege to opportunity thought, heart, religion and convictions, in this manner adding to the ethical, moral, profound and scholarly needs of ladies and men, independently or in the public eye with others consequently guaranteeing the chance to live their lives etstvie with their very own desires. It additionally portrayed worldwide difficulties, the acknowledgement of women's rights, whose sexual orientation effect has not been deliberately completely assessed. Nonetheless, small-scale overviews demonstrate that there is a need to audit arrangements on business and nature of work. The advantages $f$ developing worldwide economy are unevenly conveyed, bringing about more noteworthy monetary inconsistencies, feminization of destitution, expanding sexual orientation imbalance through frequently declining working conditions and problematic workplaces, particularly in the casual division and rustic zones. She recommended arranging projects to acquaint women with their rights. The legislature must be available to guarantee that there is no oppression the woman and her rights are ensured. Training is an incredible asset for engaging women. That is the reason unique consideration ought to be paid to the instruction of women.

Juliet Hunt (2002) says that to reduce destitution and improve the status of women, microfinance projects assume a significant job. It finds the solid connection between access to credit and the empowerment of women's status in the family as well as in the network. In this article, microfinance should engage women. The specialist has utilized research methods and has met more than three weeks with female gatherings and staff from three NGOs in Bangladesh and one headquartered in Bihar, India. These NGOs give women microfinance for enabling and decreasing neediness. The analyst contends that advancement offices are focused on engaging women. It is important to explain credit issues that control the credit and its pay, which have the ability to choose the advance and the pay, how to utilize it, which oversees pioneering exercises though credit, authority over the buy and clearance of items available. Though these inquires, the prompts the strengthening of women. Research discoveries demonstrate that a minority of women who have acquired however do not control it. The vast majority of them assumed a side job in this procedure and for the most part held their companions, children, and other male individuals as an advance. Ladies do not approach pay, they are created by credit, and men just give them enough cash to pay the advance week by week. At times advance administration has been increasingly entangled, as women have held a little advance for their own organization and have remained exchanged to men. The scientist has demonstrated that most of women have filled in as unpaid work, and men run business. Choices on the utilization of credit, the age of pay through business is in the hands of men. As indicated by the analyst's report, women have not profited by microfinance and there has been no adjustment in women's lives since they have no basic leadership control, no pay control, advertising, etc. At the point when the advance is utilized underway, it will be powerful and helpful for mitigating neediness; generally, microfinance projects will fall flat. The scientist found that training is a significant factor in expanding the status of women.

Their finding was that the biggest microcredit projects do not and cannot contact the most unfortunate individuals because the least fortunate women will never have the option to reimburse the 
credit. Mushumbusi and Jan Kratzer (2013) express that the circumstance of women dressed in Tanzania is low in contrast with men because of their customs. Ladies have a terrible status because of culture, taboos and traditions, low training. Engaging women is the focal issue in Tanzania. The scientist contends that microfinance programs, generally centered around ladies, since ladies are a decent hazard factor, don't mishandle the credit, share the advantages with their family, particularly kids, capable and committed than men, and when they get money related soundness, it will absolutely subjective and quantitative research. They said that microfinance is normal assume a significant job is lessening neediness and improvement.

Explains that microfinance is a budgetary administration for poor women who are unfit to improve their monetary status and are not monetarily solid to deal with their organization. Microfinance prompts the strengthening of women. This makes them certain and dynamic in deciding. Malik Mohammad, Pervez Zamurad Jiangsu and Qiafat Yolah (2011) women are a large portion of the all-out populace of Pakistan and the greater part of them live in remote provincial territories underneath the neediness line. They are the most helpless and denied portions of the society. For significant and manageable monetary advancement, women's support in financial exercises is similarly as significant as men. Due to restricted chanced and assets, women's cooperation in rustic territories is likewise low, so fitting advances are required. The principal microfinance bank (FBB) is workingeffectively in these remote zones. As indicated by the analyst, ladies interest is just $10 \%$ enlisted in the official area, showing that ladies have fewer open doors in the formal part, while in the causal areas there are numerous however unpaid. Furthermore, the female just has a 5\% standard in the open part, which is presently up to $10 \%$, yet just $2.8 \%$ of them work in the open area.

Manis Kumar, Narendra Singh Bora, and Amar Johari brought up that India is the second biggest city on the planet, as indicated by the World Bank, it is falling under low pay, and per capita salary is just \$3262. The outcome is a low rate of training, medical issues, low expectation for everyday life. Generally, individuals occupied with the horticultural area. To prevail in India, agribusiness must enable the rancher by making cultivating productive, and not by confiscating it for that specific reason, the rancher must be subsidized for their essential and little needs. Microfinance is relied upon to it is along these lines important to share encounters and materials that will help not exclusively to get victories and disappointments, yet in addition to give information and direction to fortifying and growing microfinance programs. The procedure intercession can be comprehended utilizing the accompanying table. A definitive is to accomplish social and monetary strengthening. Effective mediation hence relies upon how every one of these stages is deliberately considered, just as on the capacity of actualizing associations to accomplish a definitive objective, for instance, if credit conveyance is managed without the union of SCC, it might have issues with itself its - security and recuperation. In the course of recent years, fruitful involvement in giving money to little business visionaries and makers has appeared needy individuals, when offered access to responsive and convenient monetary administrations at market costs, reimburse their advances and use incomes to expand their incomes and resources [6]. This not astonishing, as the main practical option for them is to get from the casual market at a lot more prominent enthusiasm than market costs. Network banks, non-legislative associations and programs sparing gatherings around the globe have demonstrated that these small-scale advances can be gainful to borrowers and loan bosses, making microfinance a stand out amongst the best destitution decrease methodologies.

This is illustrative paper dependent on auxiliary information. Google on different sites has recognized information; inquireabout papers, and magazines. Niaz Hussain Malik and Muhammad Luqman (2005) examine e that about 60\% of worldwide microfinance customers are women. There are 
numerous motivations to offer need to ladies, for instance, first, destitution decrease, effectiveness additions, and third, strengthening. Strengthening is the procedure of progress to settle on their lives. By engaging, they increment their confidence, confidence and regard. As per the scientist, miniaturized scale credit plans seem, by all accounts, to be helpful to women's strengthening and neediness mitigation, yet there are additionally some negative ramifications for women's strengthening. Past scientists guarantee that women do not for the most part approve; they have gotten some level of strengthening [4]. Since strengthening is an exceptionally perplexing procedure to change the life of the individual with the goal that the projects for smaller scale credit have both a positive and a negative effect on engaging ladies and mitigating destitution around the globe. Emphatically, this influences women to build their certainty, basic leadership, improve family and furnish them with social, money related and monetary chances. Then again, women work in a constrained domain and their investment in pay creating exercises expand their outstanding task and duties Sulaamman D. Mohammad, Gaza Shahib, Cedd Iqbal Hussain Naqi and Saba Zehra (2012) featured the viability of micro financing in enabling women. The women's empowerment index and the Pakistan Statistics Scorebook assemble information for this examination. They utilized Johansen's reconciliation way to deal with survey the long haul connects between destitution, development and microfinance and the strengthening of women. The scientist found that there is appositive and huge connection between women's strengthening and microfinance, and destitution is additionally huge and has negative connection with the strengthening of women.

\section{Information and approach}

In this examination, we inspect the connection between smaller scale credit and strengthening of women. For this reason, the creator uses look into strategies to discover the outcomes. The survey was set up for the investigation. Two banks from the Khairpur area have taken to gather information. 60 women chosen by the first FMFB and 60 with a complete example of 120 for the examination

\subsection{Client Age}

The outcome demonstrates that a large portion of the customers were more than 40, may be in light of the fact that they are progressively mindful, preserving, it is additionally conceivable that they don't utilize the advance themselves, they are just supporters of their male individuals.

Table 1 Client' age group evaluation

\begin{tabular}{|l|l|l|}
\hline & Frequency & Percentage \\
\hline $20-40$ & 30 & $25 \%$ \\
\hline $41-50$ & 50 & $42 \%$ \\
\hline $51-60$ & 40 & $33 \%$ \\
\hline Total & 120 & $100 \%$ \\
\hline
\end{tabular}

\subsection{Status of instruction}

Plainly, the instructive profile of our rustic women is extremely awful, of just 120 women, just 30 have gotten introductory training and 10 have gotten advanced education. This is the principle motivation behind why our women are disheartened right up until the present time.

Table 2 School, Primary, College, University Evaluation

\begin{tabular}{|l|l|l|}
\hline & Frequency & Percentage \\
\hline No School & 80 & $67 \%$ \\
\hline Primary Level & 30 & $25 \%$ \\
\hline College and university & 10 & $8 \%$ \\
\hline
\end{tabular}




\subsection{Conjugal status}

It is uncovered that wedded women are principally occupied with financial exercises. Their offer is higher than unmarried women are. The study demonstrates that at times women are constrained by their male individuals to assume acknowledgement for budgetary help.

Table 3 Married, unmarried, widow and Divorce evaluation

\begin{tabular}{|l|l|l|}
\hline & Frequency & Percentage \\
\hline Married & 70 & $59 \%$ \\
\hline Unmarried & 40 & $33 \%$ \\
\hline Widow & 05 & $04 \%$ \\
\hline Total & 120 & $100 \%$ \\
\hline
\end{tabular}

\subsection{Business Nature}

For the most part women take an interest in the casual area because of absence of instruction and budgetary issues.

Table 4 Business nature Tailoring, Poultry, Livestock, Boutique and parlor evaluation

\begin{tabular}{|l|l|l|}
\hline & Frequency & Percentage \\
\hline Tailoring and Handicraft & 50 & $42 \%$ \\
\hline Poultry & 10 & $08 \%$ \\
\hline Livestock & 30 & $25 \%$ \\
\hline Boutique and parlor & 30 & $25 \%$ \\
\hline Total & 120 & $100 \%$ \\
\hline
\end{tabular}

\section{The old business or is it begun?}

Generally, women have begun business before assuming acknowledgement; however, they face money related issues to deal with the business.

Table 5 Old new business evaluation

\begin{tabular}{|l|l|l|}
\hline & Frequency & Percentage \\
\hline Old & 90 & $75 \%$ \\
\hline New & 30 & $25 \%$ \\
\hline Total & 120 & $100 \%$ \\
\hline
\end{tabular}

\subsection{Paid sum}

Most women have independent companies and take an interest in the casual part, so they take a short advance sum without much of stretch reimbursed. As the commitment of credits, they pay week by week or month to month.

Table 6 Paid sum of salaries evaluations

\begin{tabular}{|l|l|l|}
\hline & Frequency & Percentage \\
\hline $15000-20000$ & 60 & $50 \%$ \\
\hline $21000-35000$ & 10 & $08 \%$ \\
\hline
\end{tabular}




\begin{tabular}{|l|l|l|}
\hline $36000-60000$ & 20 & $17 \%$ \\
\hline $60000-$ and above & 30 & $25 \%$ \\
\hline Total & 120 & $100 \%$ \\
\hline
\end{tabular}

\subsection{Who offers you for credit?}

Table 7 Credit offer to relatives, friends and Banks institutions

\begin{tabular}{|l|l|l|}
\hline & Frequency & Percentage \\
\hline Relatives & 20 & $17 \%$ \\
\hline Friends & 40 & $33 \%$ \\
\hline Bank and institutions & 60 & $50 \%$ \\
\hline Total & 120 & $100 \%$ \\
\hline
\end{tabular}

Most women express that brokers have roused them to join the microfinance program. They go way to way to publicize their plans and make it simpler for compatriots.

\subsection{Where do you spend a credit?}

The study found that most women spend a large portion of their credit from their business and the other half out of their own costs. Along these lines, the fundamental reason for the credit is finished and is not useful to them.

Table 8 Credit spend on business, self-expenditure \& on both evaluations

\begin{tabular}{|l|l|l|}
\hline & Frequency & Percentage \\
\hline On business & 20 & $17 \%$ \\
\hline On self-expenditure & 30 & $25 \%$ \\
\hline On both & 70 & $58 \%$ \\
\hline Total & 120 & $100 \%$ \\
\hline
\end{tabular}

\subsection{Who chooses the advance?}

Table 9 Yes, advance self and Husband and male members

\begin{tabular}{|l|l|l|}
\hline & Frequency & Percentage \\
\hline Self & 30 & $25 \%$ \\
\hline Husband and male members & 90 & $75 \%$ \\
\hline Total & 120 & $100 \%$ \\
\hline
\end{tabular}

The outcome demonstrates that women do not get, they are only an approach to help their male individuals. They have no basic leadership control.

\subsection{Month to month pay}

The vast majority of the respondents have a place with the pay gathering (5000-1000), so the dominant part live beneath the destitution line. Their expectation for everyday comforts is exceptionally low. They cannot effectively meet their fundamental needs.

Table 10 Month to Month pay salaries evaluation

\begin{tabular}{|l|l|l|}
\hline & Frequency & Percentage \\
\hline $5000-1000$ & 50 & $42 \%$ \\
\hline $10000-20000$ & 40 & $33 \%$ \\
\hline 30000 and above & 120 & $100 \%$ \\
\hline
\end{tabular}




\subsection{Month to Month expenses}

Most respondents state their month to month spending is 10000-20000, so its extremely hard for them to pay commitments on schedule and then again to deal with their family unit costs.

Table 11 Month to month expenses salaries evaluation process

\begin{tabular}{|l|l|l|}
\hline & Frequency & Percentage \\
\hline $10000-20000$ & 60 & $50 \%$ \\
\hline $20000-30000$ & 40 & $33 \%$ \\
\hline 30000 above & 30 & $17 \%$ \\
\hline Total & 120 & $100 \%$ \\
\hline
\end{tabular}

\subsection{Who chooses pay and expenses?}

Of 120 respondents, 70 respondents said that their better half settled on salary and costs, we are just a sources. We pay a regularly scheduled payment, and male individuals give just the measure of the commitment.

Table 12 Pay and expenses of self, husband and both evaluation

\begin{tabular}{|l|l|l|}
\hline & Frequency & Percentage \\
\hline Self & 10 & 08\% \\
\hline Husband & 70 & $59 \%$ \\
\hline Both & 40 & $33 \%$ \\
\hline Total & 120 & $100 \%$ \\
\hline
\end{tabular}

4.8 Do you contribute? Under time or no?

Table 13 Contribution under time or no evaluation process

\begin{tabular}{|l|l|l|}
\hline & Frequency & Percentage \\
\hline Yes & 70 & $59 \%$ \\
\hline No & 50 & $41 \%$ \\
\hline Total & 120 & $100 \%$ \\
\hline
\end{tabular}

Most of individuals pay the credit in time. 50 respondents said they had money related issues so they could not pay commitments on schedule. The litigant brought up that, specifically, the measure of the credit is spent on other essential needs, so this sum is not valuable to us, and it does not put appropriately in business exercises, so it is hard to pay the portion on schedule.

\subsection{When you take up your budgetary position we become better or no?}

Table 14 Budgetary position become well or no evaluation process

\begin{tabular}{|l|l|l|}
\hline & Frequency & Percentage \\
\hline Yes & 40 & $33 \%$ \\
\hline No & 80 & $67 \%$ \\
\hline Total & 120 & $100 \%$ \\
\hline
\end{tabular}

The information demonstrate that the monetary state of the respondent turns out to be less great after the credit, as the measure of the advance and the enthusiasm on it are hard to pay, in this way, they are experiencing tension in the wake of accepting the advance. 


\subsection{Do you feel enabled?}

Table 15 Feel enabled for yes or no evaluation process

\begin{tabular}{|l|l|l|}
\hline & Frequency & Percentage \\
\hline Yes & 30 & $25 \%$ \\
\hline No & 90 & $75 \%$ \\
\hline Total & 120 & $100 \%$ \\
\hline
\end{tabular}

The outcome has demonstrated that microfinance projects are not completely enabled for women. It is uncovered that the measure of the advance is not utilized accurately in business exercises. A little measure of advance from private company that remaining parts to be utilized for day by day family costs so it is anything but a wellspring of pay increment and they feel additional weight for them when they cannot reimburse the credit on schedule.

\section{Conclusion}

In the region of Haiphrop, microfinance projects are not a total wellspring of strengthening for women, different elements influence women's strengthening, for example, male-ruled issues and social standards and taboos. The state of the woman is not improving. They face numerous issues because of the absence of instruction and numerous different reasons we examined in the report. Microfinance projects are successful when utilized in a suitable manner and generally used to oversee business and produce salary. It will be valuable for women on the off chance that they have salary, settle on choices on homework and will be free for portability. It is proposed that preparation projects be composed by microfinance organizations and acquaint themselves with their rights. To ease destitution, the advance utilized to grow business as opposed to address individual issues. To control the pay and resource proprietorship.

\section{References}

Dr. Thresiamma Varghese, "Women empowerment in Oman", a study based on women empowerment in rural development”, Pakistan journal of distance education,, 16(7): 52-59, 1999.

Dr. Ajay Sharma, Ms. Sapna Dua, Mr. Vinod Hatwal, "Micro enterprise development and rural women entrepreneurship: Way for economic empowerment", A journal of economics and management, 1(6): 24-32, 2012.

Esther Duflo, (2012) "women Empowerment and Economic Development", journal of economics literature, (50(4):71-76, 2012.

Helge Ronin, "Economic empowerment of women through micro credit, The case of the micro finance, investment and technical assistance facility (MITAF)", Text book, SLE publication series. 1(01):43-56, 2012.

Isidore Ekpe, Norisah Binti Mat and Razali Che Razak, "The Effect of micro finance factors on women's entrepreneur' performance in Nigeria: A conceptual framework", International journal of business and social scinces, 1(2):111-121, 2010.

Islam Md. Rafiqul, “Rural women's empowerment through self income generating activities: A study on NGOs, credit programs in Bangladesh”, journal of global citizenship and equity education, 1(1): 109-115, 2011.

Juliet Hunt, "Reflection on Micro finance and women's empowerment", development Bulletin, 57:71-75, 2012. 